\title{
Political support for trade policy in the European Union
}

\author{
Joseph Francois ${ }^{\mathrm{a}, *}$, Douglas R. Nelson ${ }^{\mathrm{b}, 1}$ \\ a University of Bern, Department of Economics, World Trade Institute, Hallerstrasse 6, 3012 Bern, Switzerland \\ b Murphy Institute of Political Economy, Tulane University, New Orleans, LA 70118, USA
}

\section{A R T I C L E I N F O}

\section{Article history:}

Received 5 December 2013

Received in revised form 21 July 2014

Accepted 3 August 2014

Available online 9 August 2014

\section{JEL classification:}

D72

F13

F14

Keywords:

Political support

Endogenous tariffs

Revealed political weights

EU trade policy

\begin{abstract}
A B S T R A C T
We adopt the Stigler-Peltzman model of policy-making as developed by Hillman for application to the politics of international trade, in which the government is represented by a political support function trading-off the industry rents stemming from protection against the losses accruing to the general population. As a starting point, we examine the economic impact of actual government action as revealed by the structure of protection, backing out the weights implied by the marginal welfare effects of the set of EU import tariffs across sectors. We build on Tyers' application of methods to international trade employing a numerical general equilibrium model of the EU. This captures direct marginal effects of sector-level protection on protected industries, indirect effects on upstream and downstream industries, and the effect on overall welfare. We then deconstruct the revealed weighting pattern along the lines of industry nationality and related industry characteristics.
\end{abstract}

(c) 2014 Elsevier B.V. All rights reserved.

\section{Introduction}

The EU is a major participant in world trade and one of the pillars of the international trading order centered on the World Trade Organization. However, while every bit as significant as those of the United States, the politics underlying European trade policy are considerably less studied. It is not hard to understand why this is the case. On the one hand, the politics are substantially more complex than those in the US. In particular, like the US, EU trade policy is constrained by both domestic and international politics. Yet unlike the US, there is a layer of sovereign political power lying between domestic political pressures and the final authority on trade policy. This makes lobbying itself fundamentally more complex. At the same time, and on the other hand, the politics of trade policy-making are also less transparent in the EU than in the US. Explicit lobbying behavior in the Union, for instance, is particularly difficult to track. Not only is there no open process of legislative hearings, but unlike in the US, campaign contributions in most EU countries are heavily restricted, if not forbidden, so that lobbying comes in much less observable forms. This is crucial because in standard endogenous protection models, the amount of lobbying directly translates into weights attached by government to industry interests. As government choice hinges essentially on the issue of trade-off between competing societal and private interests, these weights determine where the policy chips will fall.

\footnotetext{
* Corresponding author. Tel.: +41316313270.

1 Tel.: +1504862 3238 .
} 
The complexity and lack of transparency in EU trade policy formation surely explains the considerably greater scarcity of theoretical and empirical analyses of the political economy of trade policy in the EU by comparison to that in the US. ${ }^{2}$ Even faced with such difficulties, given the significance of the EU in the world trading system, a more systematic understanding of the politics underlying EU trade policy seems a worthwhile goal. This is the objective of this paper. While we do not attempt to deal comprehensively with the full complexity of EU trade policy making, we do develop a method to address the unobservability problem. We adopt the Stigler (1971)-Peltzman (1976) model of policy-making, developed by Hillman $(1982,1989)$ for application to the politics of international trade. In this class of model, the government is represented by a political support function trading-off the industry rents stemming from protection against the losses accruing to the general population. ${ }^{3}$ We identify the ordering of preferences by examining the economic impact of actual government action as revealed by the structure of protection. Specifically, we build on work that shows how to back out the weights implied by the marginal welfare effects of a set of import policies. ${ }^{4}$ We build in particular on the work of Tyers, who has applied these methods to international trade in partial (Tyers, 1990) and general equilibrium (Tyers, 2004). ${ }^{5}$ Employing a numerical general equilibrium model of the EU, we estimate the direct marginal effect of sector-level protection on protected industries, the indirect effect on upstream and downstream industries, and the effect on overall welfare. ${ }^{6}$ Once identified, these marginal effects allow us to econometrically estimate the apparent weights of industry in policymaking given the current tariff structure. We then deconstruct these weights along the lines of industry nationality and other related characteristics. Unraveling national preferences is particularly important in the EU context, because while the supply of regional protection obviously corresponds to the sum of individual national demands, the common trade policy in the EU and the complexities surrounding it conceal the interplay of private, national and aggregate regional interests.

We are obviously not the first to essay a study of EU trade policy. There are a number of solid narrative studies of European trade policy (e.g. Hine, 1985; Schuknecht, 1992). More closely related are a number of empirical studies rooted in one or another of the main approaches to the political economy of trade policy. The next section situates our analysis relative to these studies. Unlike these studies, our approach follows earlier work by Bruce Gardner (Gardner, 1983, 1987, 1989) and Rod Tyers (Tyers, 1990, 2004) who develop a method for identifying the political influence of groups implied by the distortions those policies produce. We believe this approach has a number of clear advantages. Perhaps most important, the effects of protection on overall welfare, as well as on specific sectors, are fully captured. Hence, the valuation of the marginal costs and benefits of protection more adequately takes into account the economy-wide repercussions of sectoral policies. The policy weights are also backed by data. Consequently, unlike previous empirical studies, the values we obtain for these weights tie in with theoretical expectations: revealed policy weights given to industry profits, in general, tend to be around 2 to 3 times that assigned to national income or welfare. As expected, above average weights correspond with above-average tariffs for import-competing product groups. In the context of a customs union such as the EU, we also find that nationality matters, so that industries important to certain Member States in terms of relative output shares, consistently acquire higher levels of protection. Finally, the agricultural bias of EU protection emerges as a by-product, in part, of a tendency to assign importance to the strength of intermediate linkages, with upstream industries receiving relatively lower tariffs for a given policy weight.

We have organized the paper as follows. Section 2 provides further background and motivation, anchoring the present exercise to the literature. In Section 3 we examine basic patterns of EU import protection. We start in Section 3.1 with a relatively standard political economy framework for testing the relationships between sectoral tariff variations and selected industry characteristics identified as important by theory. In Section 3.2, we then examine what drives the observed patterns by employing a computational model to produce estimates of the general equilibrium marginal income effects given the actual rates and pattern of protection and production across the EU. From these marginal estimates, we estimate econometrically the implied weights for individual sectors relative to the weight assigned to overall economic welfare. This allows a ranking of industries according to the assigned relative weights. In Section 3.3 we explore how national and EU-wide industry characteristics, especially the nationality of various industries, bears on the determination of the EU-wide industry coefficients. This provides some indication of the individual policy preferences of Member States. Finally, in Section 4 we offer last observations, and then conclude.

\footnotetext{
${ }^{2}$ In fairness, trade policy-making in the US is more complex and less transparent than we often think, and certainly more complex and less transparent than theoretical models and their empirical implementations often imply. As far back as Bauer, Pool and Dexter's (1963) classic analysis of trade policy-making in the mid- and late-1950s, it has been clear that lobbying, and its relationship to final government decisions, is considerably more complex than a straightforward exchange of cash for policy ("protection for sale"). Even in that context, essentially ad hoc decisions with respect to which sectors are organized and how to measure protection (to say nothing of effects on liberalization embedded in trade bills), renders claims of a tight link between theory and empirics dubious at best. That said, the additional layer of sovereign states between citizens and the trade policy-making authority is a substantial step up in complexity.

${ }^{3}$ The Grossman-Helpman (1994), protection for sale, model, by explicitly incorporating the lobbying decisions of organized groups, is a more complete model and has been the foundation of many theoretical and empirical advances in the political economy of trade policy. However, precisely because we lack information on this lobbying, we pursue an approach that does not require such information.

${ }^{4}$ This general methodology has been best developed in partial equilibrium, with application to agricultural economic policy (e.g. Gardner, 1983, 1987, 1989; Rausser and Freebairn, 1974; Sarris and Freebairn, 1983; Swinnen, 1994, 1996; Swinnen and de Gorter, 1998; Zusman and Amiad, 1977) as well as to indirect taxes in the public economics literature (e.g. Ahmad and Stern, 1984; Christiansen and Jansen, 1978). Theoretical foundations for this approach are found in: Zusman (1976); Ross (1984, 1985); and Beghin (1990). The volume by Rausser, Swinnen and Zusman (2011) is a convenient and up to date presentation of this material.

${ }^{5}$ In general, the partial equilibrium and general equilibrium computational literature has used numerical models to calibrate policy weights for use in numerical modeling. In contrast, here we use a numerical model to estimate raw marginal policy impacts, but then turn to econometrics for analysis of the pattern of revealed weights.

${ }^{6}$ We are not the first to recognize the importance of vertical production structures in the political economy of protection. Gawande and Bandyopadhyay (2000), in one of the first tests of the protection for sale model, developed this analysis and Gawande, Krishna and Olarreaga (2012) develop the analysis yet further. More directly related to our work here is the paper by Cadot, deMelo and Olarreaga (2004), who develop their analysis in a computational general equilibrium model.
} 


\section{The political economy of protection: in general and in the EU}

The evolution of European tariffs not only reveals trends in trade protection, but also gives some indication of the liberal and protectionist forces at play across the continent. The 1968 common external tariffs (CET) of $10.4 \%$ was the arithmetical average of the Italian and French high tariffs ( $16.8 \%$ and $15.3 \%$, respectively), and the lower ones of Germany and the Benelux countries (5.8\% and $8.7 \%$ ) which were in effect before the formation of the customs union. The same differentiation can be seen in the old EFTA as well, with the UK and Austria being relatively more protectionist (14.9\%, 11.4\%), compared to their Scandinavian counterparts (Sweden, 6.3\%; Denmark, 5.2\%). After several decades, tariff protection in industrial goods has markedly declined in importance, with the simple average CET at historic a historic low, now at 3.9\% for industrial goods, and $13.9 \%$ for agricultural goods. ${ }^{7}$ Even with a falling average, peaks tariffs remain, with averages across industrial sectors ranging from $0.9 \%$ (wood and paper products) to $11.5 \%$ (clothing).

As with most countries, agricultural protection is a special case, and in the European Union it even merits a distinct Communitywide sectoral policy, the Common Agricultural Policy (a.k.a. the CAP). Free internal agricultural trade has been accompanied by a substantial increase in external protection that for years has proven to be resistant to any reform. Liberalization did make some headway in the 1990s (Messerlin 2001), but protection remains high. ${ }^{8}$ Processed sugar and dairy products, which were excluded from the 1992 CAP Reform but have been affected by subsequent reforms, still register some of the highest rates of protection, at $29.1 \%$, and $55.2 \%$ respectively. Processed rice production is likewise heavily protected (54\%), as are meats (21.9\%). Tariff peaks in the manufacturing sector are fewer in number (and except for motor vehicles, mostly agro-related: processed foods, beverages and tobacco) and at much lower rates.

In terms of output shares, services dominate the EU, with $73 \%$ of output on a value added basis. In manufacturing, the four largest sectors in the EU, in terms of the sectoring scheme of our data (discussed below), are chemicals, other machinery, motor vehicles, and electrical equipment. They account for almost $50 \%$ of manufacturing output value and $16 \%$ of all output. In each of these sectors, Germany is the largest producer. However, Germany is likewise a major producer in some important agricultural sectors, including milk and dairy products (22\% of EU output), oil seeds (44\%), and sugar (23\%). Italy's interest is particularly concentrated in textiles (24\%), apparel (35\%) and leather (43\%). These industries are also relatively important to Portugal, in terms of total output. In other tariff peak products such as rice, Italy (supplying 54\%) and Spain (31\%) have been the primary beneficiaries.

The theoretical and empirical literatures on the political economy of protection are large. ${ }^{9}$ However, as Helpman (1997) points out, virtually all models of the political economy of trade policy contain a set of common variables: the inverse of the elasticity of import demand (or export supply); and the ratio of domestic output to imports. In addition, most models should include some measure of the degree to which the policy maker values aggregate welfare (relative to private benefits somehow construed). The protection for sale model treats organization as a primitive, but it is well known at least since Olson (1965) that such an organization cannot be taken for granted. Thus many empirical studies include variables intended to capture the relative capacity for political organization: industry concentration; geographic concentration; industry scale; number of employees; unionization; etc. (see e.g. Baldwin, 1985; Busch and Reinhardt, 2000; Gawande, 1998a, b).

There are also models of endogenous protection that instead stress supply incentives, such as the electoral need of governments to win as many votes as possible. In this instance, total employment (i.e. voting strength) of the sector is key. Still others draw attention to the (conservative) politicians' aversion to changing the prevailing level and distribution of income, so that tariffs are used to compensate for the income shifts brought about by unemployment or surges in import penetration. In such a case, it is the changes, not the composition or the absolute levels of employment and imports, which explain the supply of protection. However, evidence on the extent and direction of tariff effects associated with some industry characteristics is ambiguous. Consider for example the case of the role of industry size. Larger industries are said to be politically important because of the votes they deliver. Hence, one can expect to find higher rates of protection in larger industries (Finger et al., 1982; Lee and Swagel, 1997). On the other hand, these sectors face more collective action problems, so that tariffs are likely to be lower (Trefler, 1993). Cadot, de Melo and Olarreaga (1999) also predict protection to drop in these industries as a result of general equilibrium adjustment in the labor market. ${ }^{10}$ In the Grossman-Helpman model (1994), industry size is not at all important if sector lobbying is zero. There is also an endogeneity problem, as industries that receive protection will then expand.

Even when data on campaign contributions are available, recent empirical work on US trade protection illustrates the various problems involved in capturing the extent of lobbying activities. In a survey of empirical approaches on endogenous protection, Gawande and Krishna (2003) discuss the Goldberg and Maggi (1999a) and Gawande and Bandyopadhyay (2000) tests of the Grossman-Helpman model, where data on political contributions of corporate institutions are used as lobbying indicators. Problems pointed out by Krishna and Gawande include the difficulties inherent in isolating that part of the total financial support particularly aimed at influencing trade policy, and the exclusion of non-corporate sources of electoral financial support, such as labor unions. This may have resulted in misspecifications and underestimation of the political strength of private interests, and thus may account for some curious results found in the literature. One such result is the extremely high estimate of the weights government attaches

\footnotetext{
7 See WTO (2012). Active participation in the GATT/WTO is, of course the primary source of this liberalization. These international politics, like those associated with the creation and operation of the ongoing programme of European integration, are the primary sources of the complexity we noted at the outset of this paper. We are, of course, aware that these forces can interfere substantially with inference of the sort that we propose here (e.g. Grossman and Helpman, 1995a, b). For the analysis we develop to work, it must be the case that, loosely speaking, whatever forces also determine the outcomes in these international negotiations, they do not fundamentally undermine the operation of factor- and sector-based politics.

8 See Pelkmans (2006), chapter 11, pp. 219-222, Messserlin (2001), WTO (2012).

9 For recent surveys see Helpman (1997); Gawande and Krishna (2003), Nelson (2009), and Ethier (2011).

10 Wages, and production costs rise because of the output increase initially triggered by tariffs, so that eventually the demand for protection falls.
} 
to overall welfare relative to industry rents, spanning from 100 to 3000, and the other is the very low value of total political contributions (in the range of $\$ 30$ million) relative to the large deadweight loss and producer surplus stemming from protection.

Given the prominent role assigned to lobbying, attempts are nonetheless made to indirectly craft acceptable lobby indicators so as to extend the Grossman-Helpman test to more countries. Several approaches emerge. One is to simply assume that industries fulfilling a certain set of criteria are more likely to be politically organized than others. Gawande, Sanguinetti and Bohara (2005) for instance, take MERCOSUR industries whose imports surpass the sample mean as actively lobbying for protection. Another method is to equate membership in any industry-related organization with lobbying, as in Mitra, Thomakos and Ulubasoglu (2004) in their study of Turkey. Cadot, Grether and de Melo (2003) instead illustrate an approach where the classification of industries as being politically active or passive is endogenized in a multi-stage iterative procedure. In a more recent paper, Cadot, Dutoit, Grether, and Olarreaga (2008) identify politically organized firms using trade and production data. They apply a 3-stage process where a standard Grossman-Helpman model was estimated, producing the usual results (i.e., endogenous tariffs as a function of import penetration rates, among others). They then use the residuals of the regression to rank industries, with high residuals implying greater political organization. An arbitrary cut-off value is determined, above which industries are considered to be organized. Finally, they run a grid search over different cut-off values. Another paper, by Belloc and Guerrieri (2008), assumes that the organized sectors in the EU are those populated by large firms. This is problematic since extensive firm-based studies show that it is precisely exporting sectors in Europe which are characterized by very large firms (Mayer and Ottaviano, 2008). One problem raised by Esfahani and Leaphart (2000) refers to the manner in which the coefficient of the output-import ratio is specified as a function of political organization alone, thereby giving the lobby indicator all the chances to prove significant. It becomes even trickier in cases where certain industry characteristics such as industrial concentration and import penetration are used as proxies for lobbying activity, given the many alternative channels by which these variables may affect the policy preferences of government. Also, the dilemma posed by the high weights attached to overall welfare remains, because even taking the lowest estimates derived by Cadot, et al (2008), ${ }^{11}$ the weights are such as to make any lobbying prohibitive.

Early empirical tests on the European pattern of protection have shown that despite the differences in market and production structures across members, the level of Community tariffs did not significantly change the relative protection between different sectors. Constantopoulos (1974) noted that while European countries have followed different tariff regimes, the national structure of protection in the 6 original EEC countries did not actually differ very much. Her results also show that extra-EEC protection displayed positive correlation with the relative share of unskilled labor and the level of R\&D content. This implies that regardless of differences in specialization, the same Stolper-Samuelson effects seemed to be at play in the determination of trade regimes, and that some congruence of industrial policy goals existed among the original Members.

In a pair of interesting papers, Samia Costa Tavares (Costa Tavares, 2006, 2007) has sought to understand the politics of European trade policy by looking at voting on the common external tariff in the Council of Ministers. Because there is no record of these votes, like us, Costa Tavares must take an indirect approach. In her case, this involves identifying country-level preferences based on historical tariff structures, loosely in the context of a Stigler-Peltzman-Hillman model, and then inferring the voting outcome via a framework based on models of logrolling. In Costa Tavares (2007) the analysis finds that policymaking reflects bargaining between members who are themselves influenced by national lobbies. In fact, the best specification the author finds in that paper is one where the exogenous variables are weighted according to the share of votes accorded to each country in the Council of Ministers. This implies, for instance, that the preferences of larger countries, having more votes, are given more weight in decision-making. By contrast, Costa Tavares (2006), found support for the hypothesis that the movement towards deeper integration, ushered in by the 1987 Single Market programme, did lead to a more centralized tariff-setting process. Technically, this means that the specification wherein national size or influence do not play a role (i.e. industry characteristics are merely summed up or averaged to form the EU characteristics used for estimation), would seem to explain the structure of protection better than those where the preference of the decisive country voter is what counts. Our work proceeds in a way more directly related to the political support function approach in that we do not attempt to, implicitly or explicitly, use information about details of the decision-making process.

\section{Tariffs and industry characteristics}

In this section, we examine European tariffs in a three step process. First, we apply a reduced form tariff function from Helpman (1997) based on the political support literature summarized above. This is followed by a more structured assessment, where we employ a computable general equilibrium (CGE) model to estimate both marginal welfare effects and marginal direct (own tariff) and indirect (upstream and downstream tariff) rent effects linked to the pattern of EU tariffs. We use the welfare and rent effects to estimate relative industry and welfare weights using a political support function. Finally, we deconstruct the relative industry weights, testing for the importance of political economy and nationality variables on the pattern of relative industry weights. In particular, we examine the role of industry size both EU-wide and with respect to the 12 individual national economies making up the EC12. ${ }^{12}$

\footnotetext{
11 They find, for instance, that the weight given by government to social welfare relative to contributions is 3.1 . This implies that each lobby should contribute $\$ 3$ for each dollar of deadweight loss.

12 Namely: Belgium (Bel), Denmark (Den), Finland (Fin), France (Fra), Germany (Ger), Great Britain (GBR), Greece (Gre), Ireland (Ire), Italy (Ita), Luxembourg (Lux), Netherlands (Ned), Portugal (Por), Spain (Spa), and Sweden (Swe). As Austria, Sweden, and Finland were outsiders when current rates were set (as were newer Members States) we leave them out of the present assessment.
} 


\subsection{Tariff, trade, and production data}

We work with a set of integrated social accounting data that combine import protection with input-output structures, allocation of value added (employment) across sectors, intermediate and final demand, and trade flows. These are the global social accounting data organized by the Global Trade Analysis Project (GTAP), a research consortium that includes international organizations like the World Bank, OECD, European Commission, and several UN and national agencies. We use the GTAP versions 7, 8 and 9 database, which provides data for 2001, 2004, 2007, and 2011 (see Hertel 2013 on the GTAP project and database). Within the database, European industrial production and employment flows are based on sets of Member State social accounting data originating, ultimately, with Eurostat. Tariffs are drawn from the WTO's integrated database of tariffs and bindings, as well as the UNCTAD TRAINS dataset and national schedules (see Bouet et al (2004)). These are supplemented by data on trade flows and import protection. In the case of agriculture, the data also include ad valorem equivalents of quantitative barriers.

A great advantage of these data is that we have a consistent mapping of economic flow data (intermediate demands, final goods production, imports, exports, and final demand) to corresponding trade policy data that are organized in a way suitable for computational general equilibrium modeling. In the case of the EU, our focus here, the pattern of protection vis-a-vis external trading partners will, overall, reflect the politics that have driven the EU to leave out sensitive sectors in bilateral negotiations on free trade areas, and also the sensitivity of these same sectors as reflected in MFN tariff schedules.

In what follows, tariffs by industry are represented by $\tau_{1}$. We rely on the data as outlined above for the European Union. As a measure of protection we use extra-EU trade weighted tariff rates that reflect the pattern of preferential trade arrangements, WTO concessions, and the exclusion of sectors from these arrangements. Other variables include labor force composition, sector linkages, output, imports, and price elasticities. Our measure of size $X_{i}$ is the gross value of output. In both the adding-machine and in the Grossman-Helpman models, size is expected to enhance the political value of industry rents to national leaders, who collectively exercise tariff-setting powers in the Council of Ministers. ${ }^{13}$ In theory, large industries are hindered only by free-riding in launching an effective lobby. In practice, as long as the stakes are high enough, even with many firms, the collective action problem is solved through industry associations, cooperation across lobbies, and leadership by the very large firms, so that political activities extend to influence the regional agenda-setting body (European Commission) as well. Tavares quotes Lehmann's (2003) report that in 2000 , about 2600 interest groups were active in Brussels, composed of European trade federations ( $\pm 30 \%$ ), commercial consultants ( $\pm 20 \%)$, European companies ( $\pm 10 \%)$, national business ( $\pm 10 \%)$, European NGOs $( \pm 10 \%)$, labor organizations $( \pm 10 \%)$, regional representations ( $\pm 5 \%$ ), international organizations $( \pm 5 \%)$, and think tanks $( \pm 1 \%)$. The role of size depends on the balance between the effects of free-riding on the one-hand, and the greater potential rents that follow from greater size.

Our measure of nationality of industry $M S_{i j}$ is the difference between the Member State $j$ value added share of an industry $i$ (for example motor vehicles in Belgium) and the share for the EU as a whole for that same industry. This is meant to capture the extent to which an industry is more important to a specific Member State than to the EU as a whole. We define $\theta_{i}$ as the share of output that goes to intermediate rather than final demand based on the intermediate use matrix included in our social accounting data. As emphasized by Cadot, de Melo and Olarreaga (2004), input-output linkages introduce inter-sectoral rivalries, and it thus becomes a point of interest how government weighs the welfare of upstream against downstream industries. Total sales, total imports, and the trade substitution elasticity are used to estimate $Z_{i}=\frac{X_{i}}{-M_{i}^{\prime}}$, which is the inverse of the elasticity of import demand multiplied by the ratio of domestic output $X_{i}$ to imports $M_{i}$. The variable $\gamma_{i}$ is relative low-skill intensity, defined from the social accounts data as the difference between low-skill share of employment for a specific industry $i$, relative to the share for all industries. Finally as detailed below we also estimate marginal effects of tariffs on welfare $w_{i}$ and industry rents $r_{i}$.

\subsection{The tariff function}

The theoretical basis of the work reported in this paper is a presumption that governments, however understood, trade off the pressures from organized interests against the (generally unorganized) general interest. In the case of economic policy, we can usually understand the broad distribution of interests (i.e. we can identify the gainers and losers), but the political process that actually does the trading off of those interests against the general interest is complex. In the case of trade policy in the US, for example, the realized trade policy is a product of legislation (written by Congress [made up of 535 members organized for trade policy under multiple referral into several committees]), administered by the legislative branch [especially the USITC, the ITA in the Commerce Department, and the USTR], and constrained by international commitments made in the WTO. Organized interests can approach this structure at any number of points. As we note in the introduction, trade policy making in the European union is even more complex, with a variety of Community level institutions taking responsibility for both negotiation and implementation [the European Parliament, the Council, and DG trade] as constrained by the preferences of national governments, each of which must balance the preferences of organized interests and general interests (conceived of as "Community" interests and the interests of Community citizens broadly construed).

Given this level of complexity, it is hardly surprising that most effort in the development of the theory of the political economy of trade policy focuses on the preferences of citizens. The simplest way of avoiding this complexity is to assume that citizens make policy directly via referendum as in the classic paper by Wolfgang Mayer (Mayer, 1984). While this approach does a good job of representing

\footnotetext{
${ }^{13}$ Industry size also impacts on the government objective function through its effect on aggregate welfare, so that protection imposed on larger industries also leads to larger deadweight losses.
} 
one version of a generalized public opinion constraint, at least in the case of trade policy, in abstracting from all political complexity it also loses any consideration for general interest (except as represented in the preferences of the median voter). ${ }^{14}$ An alternative way to cut through this complexity is to follow Hillman (1982), who builds on Stigler (1971) and Peltzman (1976), in simply assuming that, whatever structure and process generates the tradeoff, there is sufficient stability across time that it can be represented as a simple functional relationship. Where Hillman was interested in the evolution of protection in response to changing international prices, our concern is with identifying the equilibrium tariff in a static environment. ${ }^{15}$ Thus, we follow Helpman (1997), among others, in using a version of the Hillman model directly focused on static effects of pressure on the government choice of policy.

In addition to focusing on the static equilibrium policy, Helpman (1997) presents his analysis in a simple general equilibrium framework. ${ }^{16}$ Specifically, the government's objective function (i.e. the political support function) contains two sorts of argument: the effect of trade policy on profits of a sector relative to the free trade price (i.e. $\pi(\mathbf{p})-\pi\left(\mathbf{p}^{*}\right)$, where the star denotes the world, free trade price); and the effect of policy on aggregate welfare (i.e. $W(\mathbf{p})-W\left(\mathbf{p}^{*}\right)$, where $W($.$) denotes aggregate welfare as a function$ of prices). If we let the first magnitude be $\Delta \pi$ and the second be $\Delta W$, we can write the government's political response function as $P$ $[\Delta \pi, \Delta W]$, with protection increasing in the first argument and decreasing in the second. Letting $\tau_{j}=\left(1+t_{j}\right)$, where $t_{j}$ is the ad valorem tariff rate for good $j$, and assuming that the country is economically small, so that the domestic price after a tariff is just $\tau_{j}$, we can write $P[$.$] as { }^{17}$

$$
P(\tau)=\sum_{j \in J} \frac{1}{\alpha_{p j}}\left[\pi_{j}\left(\tau_{j}\right)-\pi(1)\right]+[W(\tau)-W(\mathbf{1})],
$$

where a value of $\tau_{j}=1$ means a tariff rate of zero and the bold arguments in the second bracketed expression represent the willingness of the government to trade off aggregate welfare against profits in sector $j$ via the $a_{p j}$ term (i.e. this is the marginal rate of substitution between general welfare and profits in sector $j$ ). The larger the $a_{p j}$, the more willing is the government to trade off sector $j$ profits at the margin to gain an increase in aggregate welfare. Of course, $\alpha_{p j}$ is a black box-that is, we have no underlying model that explains $\alpha_{p j \cdot}{ }^{18}$ As with Gardner (1983) and Tyers (2004), we take it as plausible that governments make such a tradeoff and seek to recover the relevant parameter values.

Using Eq. (1) and substituting in an explicit expression for aggregate welfare (see footnote 16), Helpman (1997) identifies the equilibrium tariff for sector $j$ which solves the government's problem as:

$$
t_{j}=\frac{1}{\alpha_{p j}} \frac{Y_{j}}{-M_{j}^{\prime}}=h_{j} Z_{j}
$$

That is, the tariff is higher: the larger is the sector's output level $\left(Y_{j}\right)$; the flatter is the import demand curve for good $j$ (i.e. less elastic import demand as given by the slope of the import demand curve-note that the accent denotes a first derivative); and the greater is the government's preference for sector $j$ profits relative to that for aggregate welfare. One of the very useful results in the Helpman (1997) paper is that most political economy models can be written in the form of the last expression on the RHS in Eq. (2). That is, the tariff is determined by economic factors (i.e. $Z_{j}$ the role of sector output and responsiveness of import demand to prices), which are the same across models, and political factors, whose specific content varies across models, but which enter the relationship in a simple multiplicative fashion. ${ }^{19}$ As such $h_{j}$ is positive for protected industries and embodies tradeoffs between general welfare and special interests. Larger output makes the tariff more valuable for the specific factors invested in sector $j$; while the more inelastic the import demand function, the lower the excess burden of the tariff. Since this excess burden affects general welfare the more inelastic is the

\footnotetext{
${ }^{14}$ It is, of course, straightforward to introduce a consideration of general interests in the preferences of individuals. For example, Davidson, Matusz and Nelson (Davidson et al., 2006, 2012) introduce a generalized sociotropic concern for unemployment into agent preferences in a referendum model of trade policy. However, such analysis tends to be very specific to the particular problem being considered.

${ }^{15}$ Hillman's interest was in the extent to which trade policy responded to offset the effect of a fall in the Foreign price, concluding that the offset is generally less than complete, so that the declining (i.e. petitioning) industry would continue to decline, but at a slower rate than would otherwise occur. This issue was pursued in a number of other papers (e.g. Brainard and Verdier, 1994, 1997; Cassing and Hillman, 1986; Choi, 2001; Van Long and Vousden, 1991).

${ }^{16}$ Helpman presents his analysis in the context of the Grossman-Helpman (Grossman and Helpman, 1994) economy, which is an $n+1$ commodity extension of the specific factors model in the presence of a freely traded Ricardian numeraire. Hillman (1982), and many of its extensions, is presented in partial equilibrium, while Cassing and Hillman (1986) and Van Long and Vousden (1991) consider standard 2-sector specific factor models. In the Grossman-Helpman economy, the assumptions of a freely traded Ricardian numeraire along with the maintained assumption that agents share identical, quasi-linear preferences mean that the economy can be analyzed essentially as series of partial equilibrium sectors. We present Helpman's version of the analysis in this section, but the details of the economy are not essential as we can see from Gardner's $(1983,1987,1989)$ partial equilibrium analysis and Tyers' (2004) extension of that analysis to the general equilibrium trade context.

${ }^{17}$ Helpman derives aggregate welfare by integrating over household preferences to obtain: $W(\tau)=L+\sum_{j \in J}\left(\tau_{j}-1\right) M_{j}\left(\tau_{j}\right)+\sum_{j \in J} \pi_{j}\left(\tau_{j}\right)+\sum_{j \in J} S_{j}\left(\tau_{j}\right)$, where $L$ is the total earnings of labor (given the freely traded Ricardian numeraire and choice of units so that one unit of labor produces one unit of the numeraire, this is also the total endowment of labor); the second term is tariff revenue; the third is aggregate rewards to specific factors; and the fourth is consumer surplus. For a more detailed development of this model structure, see Section 2 of Grossman and Helpman (1994).

${ }^{18}$ Note that this is in contrast to voting and lobbying models where the political institution is explicitly modeled. The protection for sale model is a hybrid. On the one hand, the lobbying behavior of interest groups is modeled, as in Findlay-Wellisz type models, as expenditure of resources by utility maximizing factor-owners, but the government, while politically active (i.e. explicitly modeled as a player in the menu auction game) is still essentially a black box.

${ }_{19}$ In referendum models (e.g. Mayer, 1984) this term reflects the preferences of the median voter, in a lobbying model (e.g. Findlay and Wellisz, 1982) this involves factors that determine lobbying effort; and in the Grossman-Helpman (1994) protection for sale model this involves whether or not a sector is organized as well as factors that determine lobbying effort for organized sectors.
} 
Table 1

PQML estimates, tariff rate $t$.

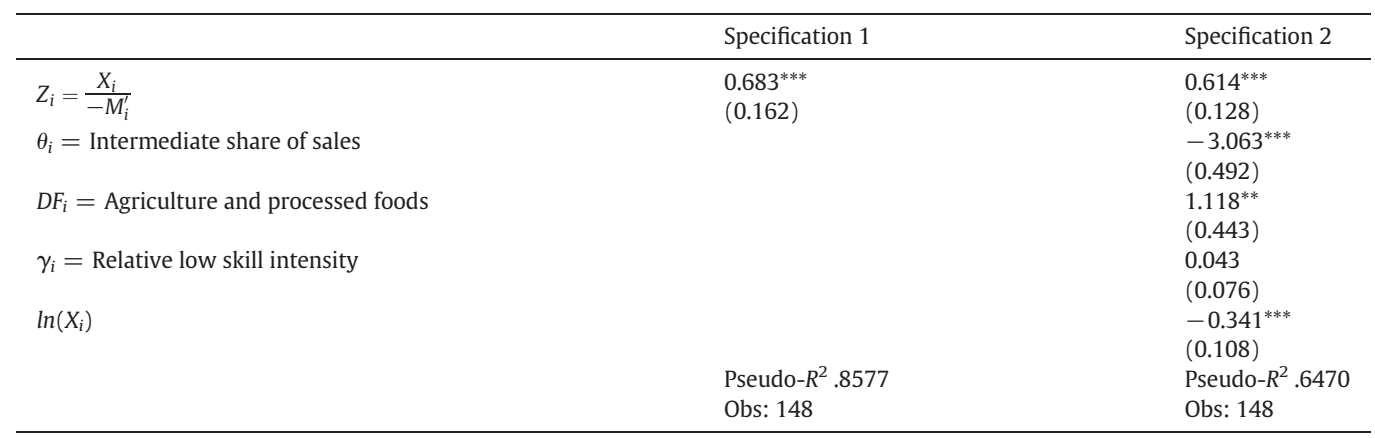

Specification 1 includes sector fixed effects.

Specification 2 includes Member State fixed effects, as discussed in Table 2. Standard errors are reported in parentheses.

${ }^{* * *} \mathrm{p}<0.01,{ }^{* *} \mathrm{p}<0.05,{ }^{*} \mathrm{p}<0.1$ based on PQML estimates.

import demand function, the higher is the equilibrium tariff ceteris paribus (this is the Ramsey rule). Because the tariff is bound from below by zero, we employ the following specification with a Poisson quasi maximum likelihood (PQML) estimator:

$$
t_{j}=e^{\sum_{k} \beta_{k} h_{k i}+\ln \left(Z_{k}\right)}
$$

In Eq. (3) we have expanded the term $h_{j}$ from Eq. (2). Table 1 presents PQML estimates of Eq. (3). ${ }^{20}$ We have reported two sets of estimates. In the first, we have included industry fixed effects to capture the terms $h_{j}$. In the second we have instead used our Member State variable as defined above, breaking $h_{j}$ down into intermediate linkages, labor composition, and our dummy for agriculture and processed food sectors as in Eq. (3). As predicted by theory, the coefficient on $Z_{j}$ tells us the tariff is increasing in the ratio of production to imports, and is higher for higher import demand functions. From the second column of results, tariffs are also higher for industries that are more intensive in unskilled labor. We also find that intermediate linkages matter in this setup. This is consistent with the results in Cadot, de Melo, and Olarreaga (2004), and consistent with the idea that industries lobby for their own tariffs, but lobby against upstream tariffs. We follow up on this in the next subsection.

\subsection{Estimating and deconstructing industry weights}

We next estimate the objective function of the reduced-form regional policymaker, say for simplicity, an EU "Über-Commissioner." Our goal is to express the level of EU-wide protection as the outcome of the Commission's maximization problem with respect to this objective function. This has the advantage of capturing the general equilibrium effects of protection, where for example steel protection may hurt motor vehicles, thereby providing more insight into the interaction of policy choice and the cost and benefits that this choice implies.

We proceed by specifying the objective function for the policy maker as follows:

$$
\Omega=\mathrm{a} w+\sum_{j} b_{j} r_{j}
$$

where $a$ and $b_{j}$ correspond to the weights attached to Community $(w)$ and industry welfare or rents $\left(r_{j}\right)$, respectively. ${ }^{21}$ Assuming that tariffs (and potentially other policy instruments) are set to maximize this function, the equilibrium tariff rates will map to the following set of first order conditions:

$$
\frac{\partial \Omega}{\partial \tau_{j}}=a \frac{\partial w}{\partial \tau_{j}}+\sum_{j} b_{j} \frac{\partial r_{j}}{\partial \tau_{j}}=0
$$

\footnotetext{
${ }^{20}$ Following Egger et al. (2011) we control in the Poisson regressions for potential selection bias, in this case with respect to the group of products with zero tariffs. Stata code and datasets are available on request.

21 Although Eq. (4) looks something like the implementation of the protection for sale model (Grossman and Helpman, 1994) in Goldberg and Maggi (1999b), but it should be recalled that there is no explicit demand side to the Stigler-Peltzman-Hillman model. Rather, these parameters simple reflect the preferences of the trade policy making entity. As we have noted, this is precisely what makes this approach an attractive framework for the research reported here. Assuming the economic structure and optimization by the government, we can recover the political weights as in Gardner $(1983,1987)$, Tyers (1990, 2004), and the extended development in Rausser et al. (2011).
} 
Rearranging this, we then have,

$$
\frac{\partial w}{\partial \tau_{j}}=-\frac{b_{j}}{a} \frac{\partial r_{j}}{\partial \tau_{j}}-\sum_{k \neq k} \frac{b_{k}}{a} \frac{\partial r_{k}}{\partial \tau_{k}} .
$$

Our data for the left- and right-hand sides of Eq. (6) come from applying marginal shocks to tariffs in a CGE model of the EU economy for years 2001, 2004, 2007, and 2011. ${ }^{22}$ Operationally, we derive these by applying small (1\%) changes in EU external tariffs across goods sectors within the general equilibrium model, and using the model to then estimate the direct and indirect impact of each tariff on overall economic welfare (measured as equivalent variation) and also on capital income within each sector. In the context of the model, this yields changes to capital income to each sector (where we treat capital as specific to a sector) as well as changes in overall national income. This in turn lets us calculate the corresponding marginal impact in social welfare, measured by equivalent variation. ${ }^{23}$ Equipped with an assessment of welfare effects, we are then able to evaluate econometrically the relative weights $b_{j} / a$ for these sectors given the actual pattern of tariff protection, production, and trade in the EU.

Maximum likelihood estimates of relative industry weights are reported in Table 2, based on Eq. (5). We start with a simple specification with trade-offs between welfare are rents (essentially an average weighing for industry rents relative to the welfare impact). These results are shown in the first column. This is followed by a split between direct rents (for the sector receiving protection) and indirect rents (for the sectors upstream and downstream). These results are shown in column 2 . We then proceed with two decompositions. The first focuses on industry level characteristics, including interaction of direct rents with size, interaction with relative (low skill) labor intensity, and with whether the sector is an agriculture or processed food sector. In the final decomposition, we have weighted the full set of rents from each experiment by our Member State variable. Several points are stand out from the results. First, unlike the recent literature based on U.S. political contributions data, we do not get phenomenally high national income/welfare weighting ratios. Indeed, in general, welfare weights tend to be around one half the corresponding weight on national income/welfare. When we employ the split between direct and indirect rents in the second column, we find that on average this holds across industries, in other words, special interests receive a higher weight than Community welfare does. Another observation is that while manufacturing sectors all receive considerably less protection compared to agriculture, their policy weights are actually comparable. Indeed, from the third column, once we control for the mix of direct and indirect effects, agriculture receives a somewhat lower weighting. (This implies that there may not be much correlation between tariffs and weights, as reflected in Table 1 vs Table 2.) As noted earlier, agricultural protection in Europe has deep political and historical roots, and results here seem to suggest that tariffs are now currently high in agriculture, not strictly because of the political power of farmer groups, but because of the low economywide effects that agricultural protection implies, combined with limited downstream industry effects. Basically, because the downstream consumers of processed food products are final consumers rather than industries, there is less scope for downstream lobbying against food protection. Basically, giving in to the demands of the food industry carries relatively little negative implications for other industries compared, for example, to steel. ${ }^{24}$

Finally, turn to the last column in Table 2, where we focus on the influence of individual members, this time on the determination of the implicit policy weights assigned by the EU on various industries. The Member State terms are meant to identify potential patterns of nationality within our overall scheme of EU industry weighting. On one side, Germany stands out as receiving relatively strong weighting, in terms of higher weight to industries that are more important to Germany than to the EU as a whole. Though not as strong as the German effect, this pattern of higher relative weighing also holds for Italy, Ireland, Finland, and to a lesser extent Austria. On the other side, industries relatively more important to Belgium \& Luxemburg, the Netherlands, and to a lesser extent Spain, receive less weighting.

Overall, the pattern of results in Table 2 point to greater weighting related to overall industry size and (low) skill intensity, with underlying variation also linked to the nationality of industry with the EU. Agriculture, once we control for upstream and downstream effects, no longer stands out a special (in contrast to Table 1).

\section{Conclusions}

The applied literature on political economy determinants of import protection is largely focused on the US. Yet the EU offers a contrasting model. Both are customs unions, though they differ greatly in age. They also differ in that Member State governments play a more direct trade policy role in the EU than do state governments in the US. There are numerous difficulties one can expect in directly

\footnotetext{
${ }^{22}$ We work with a standard version of the GTAP model. We apply the model with a two-region version of the dataset, the two regions being the EU and the rest of the world. The actual model files used to estimate the marginal effects are available for on request or for download. We refer the reader to Hertel et al (1997) for the blowby-blow on algebraic structure, and Hertel (2013) for a general overview of model and data. Note that while we are working with tariffs, one could add other industrial and tax policies to the mix. In theory, for each policy in isolation, the corresponding version of Eqs. (3) and (4) should hold.

${ }^{23}$ The goods sectors in the CGE model are grains, vegetables, fruit, nuts, oil seeds, plant-based fibers, crops nec, livestock, animal products nec, milk (unprocessed), animal fibers, forestry, fisheries, primary energy, minerals nec ruminant meats, meat products nec, vegetable oils and fats, dairy products, processed rice, sugar, food products nec, beverages and tobacco products, textiles, wearing apparel, leather products, wood products, paper products, publishing, petrochemicals, chemicals rubber \& plastics, nonmetallic mineral prods, ferrous metals, nonferrous metals, metal products, motor vehicles and parts, transport equipment nec, electronic equipment, machinery \& equipment nec, manufactures nec. Out of curiosity, we also experimented with including a measure of rest-of-world welfare effects. The rest of world receives no significant weighting, based on regression results. The full estimating equation also includes indirect service sector effects (not shown), though we do not have direct service sector tariffs or marginal perturbations in the model.

${ }^{24}$ Put another way, heavy protection for steel would have heavy ramifications for construction, motor vehicles, and the machinery sector, whereas protection of rice only hurts consumers, and not so much competing industries. Industries lobby, consumers not so much.
} 
Table 2

ML estimates of relative weights.

\begin{tabular}{|c|c|c|c|c|}
\hline & Specification 1 & Specification 2 & Specification 3 & Specification 4 \\
\hline b & $-0.624^{* * *}$ & & $-0.548^{* * *}$ & \\
\hline$-\bar{a}$ & $(0.039)$ & & $(0.034)$ & \\
\hline$b_{\text {direct }}$ & & $-0.577^{* * *}$ & & \\
\hline$-\frac{a}{a}$ & & $(0.034)$ & & \\
\hline$b_{\text {indirect }}$ & & $-0.612^{* * *}$ & & \\
\hline$-\frac{a}{a}$ & & $(0.030)$ & & \\
\hline$D F_{i}=$ Agriculture and processed foods & & & $\begin{array}{l}0.100^{* *} \\
(0.040)\end{array}$ & \\
\hline$\gamma_{i}=$ Relative low skill intensity & & & $\begin{array}{l}-0.194^{* * *} \\
(0.050)\end{array}$ & \\
\hline$X_{i}($ size $)$ & & & $\begin{array}{l}-0.006^{*} \\
(0.003)\end{array}$ & \\
\hline Belgium/Luxemburg & & & & $\begin{array}{l}0.031^{* * *} \\
(0.008)\end{array}$ \\
\hline Denmark & & & & $\begin{array}{l}0.012 \\
(0.025)\end{array}$ \\
\hline France & & & & $\begin{array}{l}0.147 \\
(0.222)\end{array}$ \\
\hline Germany & & & & $\begin{array}{l}-0.912^{* * *} \\
(0.328)\end{array}$ \\
\hline Greece & & & & $\begin{array}{l}-0.053 \\
(0.117)\end{array}$ \\
\hline Ireland & & & & $\begin{array}{l}-0.567^{* * *} \\
(0.125)\end{array}$ \\
\hline Italy & & & & $\begin{array}{l}-0.769^{*} \\
(0.463)\end{array}$ \\
\hline Netherlands & & & & $\begin{array}{l}0.971^{*} \\
(0.513)\end{array}$ \\
\hline Portugal & & & & $\begin{array}{l}0.018 \\
(0.027)\end{array}$ \\
\hline Spain & & & & $\begin{array}{l}0.204 \S \\
(0.156)\end{array}$ \\
\hline United Kingdom & & & & $\begin{array}{l}0.252 \\
(0.365)\end{array}$ \\
\hline Austria & & & & $\begin{array}{l}-0.626 \S \\
(0.476)\end{array}$ \\
\hline Finland & & & & $\begin{array}{l}-0.418^{* *} \\
(0.194)\end{array}$ \\
\hline \multirow[t]{3}{*}{ Sweden } & & & & $\begin{array}{l}0.225^{* *} \\
(0.093)\end{array}$ \\
\hline & $R^{2} .8308$ & $R^{2} .8418$ & $R^{2} .8503$ & $R^{2} .5728$ \\
\hline & Obs: 148 & Obs: 148 & Obs: 148 & Obs: 148 \\
\hline
\end{tabular}

Standard errors are reported in parentheses. ${ }^{* * *} \mathrm{p}<0.01,{ }^{* *} \mathrm{p}<0.05,{ }^{*} \mathrm{p}<0.1, \S \mathrm{p}<0.2$ based on ML estimates.

observing the political economy underpinnings of trade policy in such a Union, where overt lobbying and political contributions can be illegal, and where the policy mechanisms themselves have evolved in both ambition and complexity. We work around this problem by using an alternative approach - general equilibrium estimates of the impact of EU trade policy - to directly estimate the revealed relative political weights assigned to industry. From this starting point, we have explored basic correlations found and discussed in the literature. Results show that industry size favors protection, while strong downstream linkages favor openness. Skill intensity also matters in the EU.

To further understand how sectoral interests are valued by policymakers, we have estimated the marginal effects of protection on overall and industry incomes as they are specified in the objective maximization problem of an influence-driven government model. Using a general equilibrium framework to explicitly derive these estimates, we are then able to extract the apparent weights of various industries in the policy process. This also allows us to further deconstruct these weights along the lines of industry nationality and other related characteristics.

Results show several factors reflected in the estimated political weights. First is the role of output size. Standard political economy models, working under the assumption of constant-returns-to-scale, consider the marginal impact of protection on factor incomes to be neutral to size. Hence, the importance attached to industry size is conditional on the amount of lobbying in the sector, as in Grossman \& Helpman, or conditional on the amount of nominal votes it can deliver. Our estimates show that the specification where output plays a focal role provides a good fit. This is consistent with the standard comparative advantage theory of higher output being attributed to export sectors, which in general, display a greater preference for free trade. Second, the depth of intermediate linkages matters. In particular, in the complex dance of interests that defines the pattern of tariffs, and the resulting political weights, the likelihood of protection is lower (and net influence is weaker) if special consideration leads to negative consequences downstream. 
A third point is that national priorities and industry characteristics matter not only for tariffs, but also for the assignment of policy weights. Explaining why the experiments done here point to large industrial economies (Germany, but also Italy) as prominent players in EU trade policymaking (at least on the import protection side) is beyond the scope of this paper. However, the history of European integration is replete with political ordeals related to efforts to cope with British, French and Italian insistence on special treatment (the British rebate) and resistance to liberalization (France at the end of the Uruguay Round and during the Doha Round), while the German-dominated motor vehicle industry has been highly effective at maintaining tariffs roughly $4 \times$ the industrial average ( $8 \%$ vs $2 \%$ ).

Our results illustrate that the political economy bedrock of policy making is more complex than a more simple analysis would suggest. Moreover, due to the general equilibrium approach taken here, trade policy can be used to deduce the political weights that could be reflected in other policies as well. Hence, while direct evidence on national and regional preferences might not be in place, this exercise does convey some indications of the general industry weights behind a wider range of policies.

\section{References}

Ahmad, E., Stern, N., 1984. The theory of reform and Indian indirect taxes. J. Public Econ. 25, 259-298.

Baldwin, R.E., 1985. The Political Economy of U.S. Import Policy. MIT Press, Cambridge, MA.Baldwin, R.E., 1985. The Political Economy of U.S. Import Policy. MIT Press, Cambridge, MA.

Bauer, R., Pool, I.d.S., Dexter, L.A., 1963. American Business and Public Policy: The Politics of Foreign Trade. Aldine, Chicago.

Beghin, J.C., 1990. A game-theoretic model of endogenous public policies. Am. J. Agric. Econ. 72, 138-148.

Belloc, M., Guerrieri, P., 2008. Special interest groups and trade policy in the EU. Open Econ. Rev. 19, 457-478.

Bouet, A., Decreux, Y., Fontagne, L.,Jean, S., Laborde, D., 2004. A consistent, ad-valorem equivalent measure of applied protection across the world: the macmap-hs6 database. CEPII Working Paper, \#2004-22. Centre d'Etudes Prospectives et d'Informations Internationales, Paris.

Brainard, S.L., Verdier, T., 1994. Lobbying and adjustment in declining industries. Eur. Econ. Rev. 38, 586-595.

Brainard, S.L., Verdier, T., 1997. The political economy of declining industries: senescent industry collapse revisited. J. Int. Econ. $42,221-237$.

Busch, M.L., Reinhardt, E., 2000. Geography, international trade, and political mobilization in U.S. Industries. Am. J. Polit. Sci. 44, 703-719.

Cadot, O., de Melo, J., Olarreaga, M., 1999. Regional integration and lobbying for tariffs against nonmembers. Int. Econ. Rev. $40,635-657$.

Cadot, O., de Melo, J., Olarreaga, M., 2004. Lobbying, counterlobbying, and the structure of tariff protection in poor and rich countries. World Bank Econ. Rev. 18, 345-366.

Cadot, O.,Dutoit, L.,Grether, J.-M.,Olarreaga, M., 2008. Endogenous tariffs in a common-agency model: a new empirical approach applied to india. HEC Lausanne Working Paper. Faculté des Hautes Etudes Comerciales Lausanne, Lausanne.

Cassing, J.H., Hillman, A.L., 1986. Shifting comparative advantage and senescent industry collapse. Am. Econ. Rev. 76, 516-523.

Choi, J.P., 2001. Protectionist response to import competition in declining industries reconsidered. Eur. J. Polit. Econ. 17, $193-201$.

Christiansen, V.,Jansen, E.S., 1978. Implicit social preferences in the Norwegian system of indirect taxation. J. Public Econ. 10, 217-245.

Constantopoulos, M., 1974. Labour protection in western Europe. Eur. Econ. Rev. 5, 313-328.

Costa Tavares, S., 2006. Deeper integration and voting on the common european external tariff. Munich Personal RePec Archive (\#Online at http://mpra.ub.unimuenchen.de/960/. Munich).

Costa Tavares, S., 2007. The common external tariff in a customs union: voting, logrolling, and national government interests. Econ. Polit. 19, 345-368.

Davidson, C., Matusz, S.J., Nelson, D.R., 2006. Fairness and the political economy of trade. World Econ. 29, 989-1004.

Davidson, C., Matusz, S.J., Nelson, D.R., 2012. A behavioral model of unemployment, sociotropic concerns, and the political economy of trade policy. Econ. Polit. 24, 72-94.

Egger, P., Larch, M.,Staub, K.E., Winkelmann, R., 2011. The trade effects of endogenous preferential trade agreements. Am. Econ. J. Econ. Policy 3, 113-143.

Esfahani, H.S., Leaphart, S., 2000. Testing the political economy models of trade policy: a generalized methodology with an application to turkey...and some new results. Working Paper. Department of Economics, University of Illinois at Urbana-Champaign, Urbana-Champaign.

Ethier, W.J., 2011. The political economy of protection. In: Bernhofen, D.M., Falvey, R., Greenaway, D., Kreickemeier, U. (Eds.), Palgrave Handbook of International Trade. Palgrave Macmillan, Basingstoke, pp. 295-320.

Findlay, R.,Wellisz, S., 1982. Endogenous tariffs, the political economy of trade restrictions and welfare. In: Bhagwati, J. (Ed.), Import Competition and Response. University of Chicago Press/NBER, Chicago, pp. 223-234.

Finger, J.M., Hall, H.K., Nelson, D.R., 1982. The political-economy of administered protection. Am. Econ. Rev. 72, $452-466$.

Gardner, B.L., 1983. Efficient redistribution through commodity markets. Am. J. Agric. Econ. 65, 225-234.

Gardner, B.L., 1987. Causes of U.S. Farm commodity programs. J. Polit. Econ. 95, 290-310.

Gardner, B.L., 1989. Economic theory and farm politics. Am. J. Agric. Econ. 71, 1165-1171.

Gawande, K., 1998a. Comparing theories of endogenous protection: Bayesian comparison of tobit models using gibbs sampling output. Rev. Econ. Stat. 80, 128-140.

Gawande, K., 1998b. Stigler-Olson lobbying behavior in protectionist industries: evidence from the lobbying power function. J. Econ. Behav. Organ. 35, 477-499.

Gawande, K., Bandyopadhyay, U., 2000. Is protection for sale? Evidence on the Grossman-Helpman theory of endogenous protection. Rev. Econ. Stat. 82, 139-152.

Gawande, K., Krishna, P., 2003. The political economy of trade policy: empirical approaches. In: Harrigan, J., Choi, E.K. (Eds.), Handbook of International Trade. Blackwell, Oxford, pp. 213-250.

Gawande, K., Sanguinetti, P., Bohara, A., 2005. Exclusions for Sale: Evidence on the Grossman-Helpman Model of Free Trade Agreements, NAFTA-Mercosur Working Paper Series, \#4. Latin American and Iberian Institute, University of New Mexico.

Gawande, K., Krishna, P., Olarreaga, M., 2012. Lobbying competition over trade policy. Int. Econ. Rev. 53, 115-132.

Goldberg, P.K., Maggi, G., 1999. Protection for sale: an empirical investigation. Am. Econ. Rev. 89, 1135-1155.

Grossman, G.M., Helpman, E., 1994. Protection for sale. Am. Econ. Rev. 84, 833-850.

Grossman, G.M., Helpman, E., 1995a. The politics of free-trade agreements. Am. Econ. Rev. 85, 667-690.

Grossman, G.M., Helpman, E., 1995b. Trade wars and trade talks. J. Polit. Econ. 103, 675-708.

Helpman, E., 1997. Politics and trade policy. In: Kreps, D., Wallis, K. (Eds.), Advances in Economics and Econometrics: Theory and Applications. Cambridge University Press, Cambridge, UK, pp. 19-45.

Hertel, T.W.,Ianchovichina, E., McDonald, B.J., 1997. Multi-region general equilibrium modeling. In: Francois, J.F., Reinert, K.A. (Eds.), Applied methods for trade policy analysis: A handbook. Cambridge University Press, Cambridge, UK, pp. 258-299.

Hertel, T.W., 2013. Global applied general equilibrium analysis using the global trade analysis project framework. In: Dixon, P.B., Jorgenson, D.W. (Eds.), Handbook of computable general equilibrium modeling. Elsevier, Amsterdam, pp. 815-876.

Hillman, A.L., 1982. Declining industries and political support protectionist motives. Am. Econ. Rev. 72, $1180-1187$.

Hillman, A.L., 1989. The Political Economy of Protection. Harwood Academic, Chur, Switzerland.

Hine, R.C., 1985. The Political Economy of European Trade: An Introduction to the Trade Policies of the EEC. Wheatsheaf Books, Brighton, Sussex.

Lee, J.-W., Swagel, P., 1997. Trade barriers and trade flows across countries and industries. Rev. Econ. Stat. 79, 372-382.

Lehmann, W., 2003. Lobbying in the European Union: current rules and practices. European Parliament Directorate General for Research Working Paper, \#04-2003. European Parliament, International and Constitutional Affairs Division, Luxembourg. 
Mayer, W., 1984. Endogenous tariff formation. Am. Econ. Rev. 74, 970-985.

Mayer, T., Ottaviano, G., 2008. The happy few: the internationalisation of european firms. Intereconomics 43, 135-148.

Messerlin, P.A., 2001. Measuring the costs of protection in europe: European commercial policy in the 2000s. Institute for International Economics, Washington, D.C. Mitra, D., Thomakos, D.D., Ulubasoglu, M.A., 2004. Protection versus promotion: an empirical investigation. Econ. Polit. 16, 147-162.

Nelson, D.R., 2009. The political economy of protection. In: Reinert, K.A., Rajan, R., Glass, A.J., Davis, L.S. (Eds.), Princeton Encyclopedia of International Economics. Princeton University Press, Princeton, NJ, pp. 916-924.

Olson, M., 1965. The Logic of Collective Action. Harvard University Press, Boston.

Pelkmans, J., 2006. European Integration: Methods and Economic Analysis, 3rd ed. Financial Times Prentice Hall, Harlow, England.

Peltzman, S., 1976. Toward a more general theory of regulation. J. Law Econ. 19, 211-240.

Rausser, G.C., Freebairn, J.W., 1974. Estimation of policy preference functions: an application to U.S. beef import quotas. Rev. Econ. Stat. 56, $437-449$.

Rausser, G.C., Swinnen, J.F.M., Zusman, P., 2011. Political Power and Economic Policy: Theory, Analysis, and Empirical Applications. Cambridge University Press, New York.

Ross, T.W., 1984. Uncovering regulators' social welfare weights. RAND J. Econ. 15, 152-155.

Ross, T.W., 1985. Extracting regulators' implied welfare weights: some further developments and applications. Q. Rev. Econ. Bus. $25,72-84$.

Sarris, A.H., Freebairn, J., 1983. Endogenous price policies and international wheat prices. Am. J. Agric. Econ. 65, $214-224$.

Schuknecht, L., 1992. Trade Protection in the European Community. Harwood Academic Publishers, Chur, Switzerland.

Stigler, G., 1971. The theory of economic regulation. Bell J. Econ. Manag. 2, 3-21.

Swinnen, J.F.M., 1994. A positive theory of agricultural protection. Am. J. Agric. Econ. 76, 1-14.

Swinnen, J.F.M., 1996. Endogenous price and trade policy developments in central european agriculture. Eur. Rev. Agric. Econ. 23, $133-160$.

Swinnen, J.F.M., de Gorter, H., 1998. Endogenous commodity policies and the social benefits from public research expenditures. Am. J. Agric. Econ. 80, $107-115$.

Trefler, D., 1993. Trade liberalization and the theory of endogenous protection: an econometric study of U.S. import policy. J. Polit. Econ. 101, 138-160.

Tyers, R., 1990. Implicit policy preferences and the assessment of negotiable trade policy reforms. Eur. Econ. Rev. 34, 1399-1426.

Tyers, R., 2004. Implicit policy preferences and trade reform by tariff aggregates. Australian National University Economics and Econometrics Working Paper, \#445. The Australian National University, Canberra, Australia.

Van Long, N., Vousden, N., 1991. Protectionist responses and declining industries. J. Int. Econ. 30, 87-103.

WTO, 2012. WTO Tariff Profiles 2012. UNCTAD \& UNITC, Geneva.

Zusman, P., 1976. The incorporation and measurement of social power in economic models. Int. Econ. Rev. 17, 447-462.

Zusman, P., Amiad, A., 1977. A quantitative investigation of a political economy-the Israeli dairy program. Am. J. Agric. Econ. 59, 88-98. 